\title{
Protestants, Pentecostal and African Indigenous religious perspectives on COVID 19
}

\author{
Innocent Simphiwe Nojiyeza, Sinakekelwe Khanyisile Khumalo \& Nolwazi Gama \\ Department of Anthropology and Development Studies \\ University of Zululand, Faculty of Arts Building \\ KwaDlangezwa 3886, South Africa \\ Email address: nojiyezai@unizulu.ac.za \\ DOI: https://doi.org/10.46222/pharosjot.102.24
}

\begin{abstract}
When it comes to dealing with the spread of the coronavirus, there is a consensus on the approaches adopted by religious leaders regardless of whether they are Protestant, Pentecostal, or African indigenous churches. There is generally compliance with WHO regulations and lockdown regulations stipulated by various governments across the globe, including the government of South Africa. The knowledge on COVID 19, social distancing, health and hygiene promotion and resilience are some of the matters which religious leaders are contending with. From a qualitative study conducted amongst religious leaders in Northern KwaZulu Natal, South Africa, it is clear that knowledge on COVID 19 is drawn from sources which include government and the media, and social distancing and social intimacy remains contested. Religious leaders in South Africa are to a large extent complying with COVID 19 regulations and play a pivotal role as agents of social change, whilst in other parts of the world, there is massive resistance directed at governments who are perceived to be authoritarian. There is evidence that religious leaders actively participate in structures established by government to combat the spread of COVID 19, but there is an increasing need for various levels of government in South Africa to support religious organisations in the fight against coronavirus.
\end{abstract}

Keywords: COVID 19, Social Distancing, Social Intimacy, Protestant, Pentecostal and African indigenous churches.

\section{Introduction}

The World Health Organisation (WHO, 2020) published guidelines for faith-based and religious organisations to use when handling gatherings where such are permitted as endeavours to combat the spread of the coronavirus. The guidelines call for religious leaders to:

\footnotetext{
...prevent touching between people attending faith services, prevent touching or kissing of devotional and other objects that the community is accustomed to handle communally, encourage healthy hygiene among participants in faith services and other activities when gatherings are permitted, frequently clean worship spaces, sites, and buildings, conducting faith activities remotely/ virtually, practise safe burials practices, keeping the community connected, helping others, helping members manage the onslaught of worrying news, responding to situations of domestic violence, offer special prayers for the sick alongside messages of hope and comfort and communicate health protection information. (WHO, 2020)
}

The current study investigated the extent to which Protestant, Pentecostal and African indigenous churches observed the WHO protocols as well as the regulations stipulated by the Coronavirus National Command Council of the South African government chaired by 
President Cyril Ramaphosa. Protestant, Pentecostal as well as later churches share similar experiences when it comes to dealing with the COVID 19 outbreak in South Africa. Nicolaides (2021a) and Nicolaides (2021b) describes some of these churches as Eastern Orthodox, Roman Catholic, Anglican, Scottish Presbyterian and Evangelical Lutheran Church, whilst not mentioning the Methodist Church of Southern Africa in the list of 'protestant denominations'. For the purpose of this paper, the term Protestants refer to churches which broke away from the Roman Catholic Church during the Reformation period which started in Germany in 1483CE when Martin Luther challenged the Roman Catholic Church for selling indulgences using his 95 Theses and his ideas spread across the globe (Parish, 2020).

Pentecostal churches such as the Apostolic Faith Mission established in 1908 and the Assemblies of God established in South Africa in 1932, are believers in the work of the Holy Spirit (Clark, 2005). The Zionists and the Nazareth Baptist Church, established in KwaZulu Natal by its founding prophet Isaiah Shembe, are referred to as the later churches because they are neither part of the Roman Catholic Church, Eastern Orthodox Church, Anglican Church, nor Protestants and Pentecostal churches. The latter practised their religion using the Bible, but followed indigenous knowledge approaches (Clark, 2005). In the Ugandan context, indigenous knowledge and religious practices reflect on diviners, traditional healers and cultural responses to COVID 19, independent of influences from Christianity, Islam, Bahai, Hunduism, Buddhists and Jewish religions (Isiko, 2020). This paper adopts the South African context of later churches and their indigenous approaches in dealing with COVID 19.

Pityana (2020) contends that "Christian theology" assists in understanding how the church as a collective, deal with COVID 19, based on their knowledge and understanding, the interpretation of the regulations such as physical and social distancing, burial protocols, social intimacy as well as health and hygiene promotion during the coronavirus era. Koenig (2020) took Pityana's (2020) discussion of the role of theology in dealing with the pandemic further by suggesting approaches such as inter alia 'deepening the religious faith of individuals, expressing love to those we live with, using technology to continue to hug and shake hands electronically, praying and stay in contact with each other, not being reckless whilst caring for each other, paying attention to physical health by exercising, drinking water with lemon to avoid dehydration, sleeping for 7 to 8 hours, ensuring that we eat food with adequate vitamin $\mathrm{D}$, ensuring that we have adequate medication during lockdown, maintaining a close relationship with God and being religiously involved to boost one's immune system (Koenig, 2020).

Baker et al (2020) acknowledges that religious institutions are regarded as 'super spreading events' of the coronavirus in the USA, to the large extent they complied with the lockdown regulations by closing down whilst others resisted. To illustrate this resistance, Wildman et al (2020) presented evidence such as:

As of the end of the first week of March 2020, almost two-thirds of coronavirus infections (nearly 5000 cases) were traced back to "Patient 31," an individual who worshipped at Shincheonji Church of Jesus in Daegu, South Korea. The church had insisted on in-person meetings, banning health masks, praying while touching others, and refusing to turn over its membership list to health officials. Routinely accused by mainline Protestant Christian denominations of being a secretive sect, now it is being blamed for contributing to the local epidemic of COVID-19. It didn't help that the church's leader, 88-year old Mr Lee Man-hee, explained the epidemic as the Evil One fighting back against the rapid growth of the church he founded. (Wildman et al, 2020)

In different parts of the world, there is resistance amongst the religious communities to comply with lockdown regulations. In Trinidad, pastors resisted lockdown regulations and continued 
to preside over services because they viewed failure to come to church in person as demonstrating a tacit lack of faith. Reverend Tony Spell of the Life Tabernacle Church situated in Baton Rouge, USA defied lockdown regulations referring to the virus and regulations as "politically motivated" (Wildman et al., 2020). Jaja, Anyanwu and Jaja (2020) postulated that in the Free State Province of South Africa, a church service contributed in spreading coronavirus to over $80 \%$ of people in that province and in addition, over 1600 people who contracted the virus in May 2020 were linked to this church service.

Vermeer and Kregting (2020) found that it is not only church attendance in The Netherlands, but even membership of the church which accounted for the increase of people hospitalised with coronavirus related ailments. The use of virtual worshipping since the Easter of 2020, did not replace the sense of belonging to a church, the fellowship and a community of believers (Parish, 2020). For instance, a virtual Eucharist practices such as receiving a Holy Communion did not become a replacement for an Easter Celebration, in as much as the live streaming of congregations expanded to many with online resources and thus created a 'religion online' as well as 'online religion' (Parish, 2020).

In South Africa, a study conducted by Jaja, Anyanwu and Jaja (2020) found that funeral attendance remains one of the major contributory factors in the spread of the coronavirus in the Eastern Cape Province. The failure to limit the number of mourners to 50 people, failure to adhere to social distancing during funeral proceedings, sharing of food and water during funerals are some of the contributing factors. The Xhosa and other Nguni groups' culture of washing hands using one basin after attending a funeral and failure to wear face masks during funerals are also contributing factors to the spread of the coronavirus (Jaja, Anyanwu \& Jaja, 2020).

In responding to COVID-19, there is a need to understand the religious beliefs of the patients by health care workers. In clinics and in hospitals, when documenting the medical history of a patient, it is not enough to simple ask the denomination or a religion that a patient belongs to. Health practitioners such as nurses and doctors are expected to receive academic training at university or college level regarding for example why for instance, Jehovah's Witnesses are not supposed to subject themselves to blood transfusion. In the training of medical and clinical practitioners, it is imperative to incorporate e.g. Medical Anthropology, Theology and Indigenous Knowledge Systems as part of the curriculum. If health workers are equipped with knowledge of the religious beliefs of their patients, e.g. they could be in a better position to handle the grievances of the local prophet of the Nazareth Baptist Church found in this paper, regarding traditional practices of dealing with death and conducting a funeral. In a study conducted by Hashmi et al (2020), it was established that members of the Islamic faith did not adhere to protocols because according to the Holy Quran, God is omnipotent and omniscient, and therefore, there is no disease that $\mathrm{He}$ is not able to heal.

In countries such as Lebanon where the study was conducted, it remains a taboo to comply with regulations which are against the Holy Quran, and the teaching of the Prophet Mohammed. In certain circles, COVID-19 is associated with homosexuals who are perceived to be unholy and Islamic believers are of the view that they are not vulnerable to coronavirus because of their stance against homosexuality (Hashmi et al., 2020). In order to deal with the stigma associated with religious beliefs, it is imperative to involve religious leaders in attempts to prevent the spread of the coronavirus, such as observing social distance, taking medication instead of "consuming water and sacred soil found at the grave of Maronite monk Mar Charbel (Mount Lebanon) (Hashmi et al., 2020).

Fardin (2020) is of the view that religion plays a crucial role in inculcating health promotion messages such as washing of hands which is viewed as being promoted by the Prophet 
Mohammad in the Islamic faith. Moslem leaders were instrumental in closing mosques on Fridays and used the Holy Quran to encourage believers to obey the laws and COVID 19 protocols. Religion promotes longevity of life, it is a source of human character, and essentially tends to calm people who are undergoing stress (Fardin, 2020). A study conducted by Kowalczyk et al (2020) confirmed that faith, religious involvement and prayer plays an important role in dealing with the coronavirus pandemic. The large number of respondents were of the view that faith assists them to cope with the virus, give them strength to recover after hospitalisation and when they recover, they use this opportunity to repent from their sins and show humility to others (Kowalczyk, et al., 2020).

Henderson (2021) analysed global responses to COVID-19 by the religious community as a recurrent historical process, viral transit, basic health care, school closing, workplace closing, cancel public events, restrictions on gatherings, close public transport, stay at home requirement, restrictions on internal movement, international travel controls and income support. Some of these approaches are not initiated by the church, but they either need to comply or wage a war against authorities, such as the demand from the church leaders to continue with Easter Celebrations in 2021. Henderson (2021) also posits that other interventions include human capital and relational fracture, societal trust crisis, religious factor influence, and genericity of globalisation. Idowu (2020) used the 10 plagues that Egyptians faced before Pharaoh allowed the Israelites to leave Egypt to the promised land to illustrate the extent to which COVID-19 is associated with wrong doing. The participants in the study reflected on the need to conduct face to face meetings instead of online worshipping (Idowu, 2020).

Jentile (2020) also reflected on the closure of churches as a result of the lock-down regulations as part of "infringement of their right to public worship and a direct attack of their Christian faith" and the need for the church to redefine its role during the global pandemic era. Some of the innovations are elaborated by Frei-Landau (2020) such as singing on a balcony from which others could hear what is sung, using online platforms such as video conferencing and broadcasting the Passover ceremony. Onumah and Nicolaides (2021) unpacks the relationship between individuals, the religious community and the state which is based on the advancement of human rights and suggest human needs and wants and especially human rights, require consideration. Masoga (2020b) conducted interviews with 10 pastors drawn from the Evangelical Lutheran Church (5), Wesleyan Methodist Church (2), the Roman Catholic Church (2) and the Baptist Church (1). He also interviewed 16 lay pastors drawn from Evangelical Lutheran Church (5) Wesleyan Methodist Church (2), Roman Catholic Church (2), Jehovah' Witnesses (1), African Independent Churches (5) and unidentified Pentecostal church (1). He concluded that the use of WhatsApp is not always effective, depending on the generation of believers where the young generation seem to be comfortable with its usage whereas the old generation seem to be failing to cope with online services. Other findings are also on the cost implications of using online platforms, partaking in receiving the Holy Communion which is difficult or impossible to offer using online platforms and the relevance of the church and the use of social media as an innovative tool to align with the $4^{\text {th }}$ Industrial Revolution (4IR) (Masoga, 2020b).

The perspectives on COVID 19 by Protestant, Pentecostal and African indigenous religious leaders is based on the following nine thematic areas.

- The knowledge and understanding of COVID 19 by religious leaders

- Social distancing as one of government regulations introduced to reduce the spread of the pandemic.

- Social distancing practices that were practiced in African cultures 
- How hygiene and sanitation regulations were carried out during lockdown.

- The role of faith based leaders in the midst of COVID 19 outbreak.

- The involvement of faith based leaders and the extent to which they were consulted to deal with and manage COVID 19 outbreak.

- The response of the religious community to the lockdown regulations and other government directives.

- Documentation of the incidents of COVID 19 at community level or faith based settings.

- Local based mechanisms that can work better in managing or preventing COVID 19.

The paper is divided into 5 sections, i.e. introduction, methodology, findings, discussion of findings and conclusion.

\section{Epistemology of indigenous knowledge construction}

The choice of the study design was informed by "Afro-sensed" paradigm of co-constructing knowledge with study participants, whereby vernacular language, Isizulu was the main language used to collect data (Shokane \& Masoga, 2020). The research team was upfront with the positionality and reflexivity of the team who investigated religious institutions they shared sentiments with and parts of some of them with others. All measures necessary were adopted to avoid such positionality to result in biases, although the focus was on the subjective meanings that religious leaders attached to church services occurring during the COVID-19 pandemic (Ngozwana, 2018).

\section{Study participants' sampling, study design and research setting}

The study participants were drawn from Christ International Church, True Methodist Church, Church of God of Prophesy, African Evangelical Church, Baptist Church, Isililo International Church, Church of Christ, Covenant Fellowship International, Zion Church, and Nazareth Baptist Church. The 12 participants came from each of the above mentioned churches, with the Nazareth Baptist Church leaders being found in Jozini, Umhlabuyalingana, Hluhluwe as well as Mtubatuba. The religious leaders operated within traditional Zulu communities led by Amakhosi Gumede of Jozini, known as Sqakatha, Makhasa from Hluhluwe, Ngwane Traditional Authority, also known as Mqobokazi from Mbazwana, Mkhwanazi Traditional Authority from Mtubatuba, and Hlabisa Traditional Authority from eMpembeni. Data was collected using focus group discussions as well as semi structured interviews. In Jozini, within Gumede Sqakatha Traditional Authority, there was a focus group discussion attended by religious leaders only, whereas at Mbazwana, Umhlabuyalingana, Hluhluwe and Mtubatuba, the focus group discussions were attended by traditional leaders, traditional healers, religious leaders, traditional council members, local headmen and semi-structured interviews were mainly conducted with religious leaders.

The study participants were selected using snowball approaches in the case of traditional leaders, traditional healers, and faith based leaders. Snowball sampling is where research participants recruit other participants for a test or study. It is used where participants are generally hard to access. Each traditional leader invited traditional healers, traditional council members, headmen as well as faith based leaders to participate in the study. In Jozini, the faith based leaders were selected using a purposive sampling strategy (Ngozwana, 2018). Purposive sampling (also referred to as judgement, selective or subjective sampling) is a sampling technique through which the researcher relies on his or her own judgement when selecting members of a population to participate in a study. In selecting the faith based leaders, the strategy adopted was to ensure a balance between Pentecostal, Protestants, mainline and African indigenous churches. Those that fitted the criteria were selected. A focus group discussion at Jozini area, was hosted by the Christ International Church, situated within 
Gumede Sqakatha Traditional Authority, whereas at Hluhluwe, Mbazwana and Mtubatuba, the focus group discussions were hosted by Gumede Makhasa, Ngwane and Mkhwanazi Traditional authorities in their respective traditional courts.

The study was qualitative in nature and therefore as much as participants were drawn from a wide range of religious leaders, the findings are not representative of the religious community of uMkhanyakude District, but are rather the 'rich' experiences of the leaders who participated in this study. Masoga (2020b) conducted a study looking at the effectiveness of Whatsapp by Christian churches in both KZN and Gauteng provinces. He purposively selected 10 pastors from the Evangelical Lutheran Church (5), the Wesleyan Methodist Church (2), Roman Catholic Church (2) and the Baptist Church (1). He also sampled 16 lay pastors from the Evangelical Lutheran Church (4), Roman Catholic Church (2), the Wesleyan Methodist Church (2), Jehova's Witnesses (1), African Independent Churches (5) and Pentecostal churches (1). This study is building on a similar study conducted by Masoga (2020b) and added more themes, rather than the use of social media as a tool to communicate with worshippers.

\section{Data Analysis}

Cherblanc et al (2021) conducted a quantitative study where a multiple linear regression was conducted to determine which variables promote the spiritual quality of life of university employees and students in Quebec, Canada". The findings of the study confirmed a low and a negative link between gender, mental and physical health and lack of social support amongst the respondents. It was generally the divorced, and people living with disabilities who demonstrated a strong sense of spirituality, as compared to those who are not in the category of these vulnerable groups (Cherblanc, et al., 2021). The current study considered these variables, but delved deeper into the perspectives and perceptions of the participants and the sample is relatively smaller than the Quebec study which attracted 1107 students and 952 employees. The data analysis in the current study considered thematic and content analysis. Data was categorised using Atlas TI software.

\section{Ethical issues}

The current study is part of a large Social Sciences and Humanities study of the University of Zululand Faculty of Arts. The project proposal was granted an ethical clearance by the University's Research and Ethics Committee (UZREC). All the study participants fully granted consent to participate in this study. They were granted a choice to withdraw from the study whenever they felt uncomfortable. The names used in the findings section of this paper are pseudonyms which were crafted to hide the identity of the participants. All the information shared with the research team was kept confidential and anonymity was always ensured. For the duration of the study all data collected remains password protected and only the team members have access to the files (Ngozwana, 2018).

\section{The Key Findings}

The findings are presented and discussed according to 4 themes: (1) the knowledge and understanding of COVID-19 by religious leaders, (2) social distancing as one of government regulations introduced to reduce the spread of the pandemic, and social intimacy, (3) how hygiene and sanitation regulations were carried out during lockdown and (4) membership of the Command Council, the role of the church and consultations conducted by government with religious leaders. 


\title{
The knowledge and understanding of COVID 19 by religious leaders
}

The knowledge on COVID 19 by the religious leaders was to a large extent through the media, but in Jozini, Mbazwana, Mtubatuba and Hluhluwe, traditional leaders and faith based leaders were consulted by the KZN Department of Cooperative Governance and Traditional Affairs, local municipalities and local hospitals. There are faith based leaders who are members of the local command councils consisting of all the dominant stakeholders. The Department of Health through hospitals such as Benedictine Hospital situated in Nongoma (nearby Zululand District Municipality), and local clinics provided training of faith based leaders, traditional healers and other stakeholders. The training programme offered by the local or regional Department of Health focused on prevention of the spread of COVID 19 in local churches and religious bodies. Religious leaders shared their experiences and testimonies regarding their encounter with COVID 19.

\begin{abstract}
God did us a favour, only two congregants from my church were infected during the second wave of COVID 19. They were both healed after one of these believers was in isolation for 2 weeks. As pastors we visited the families of those who were infected. There are also instances where we are not able to visit families of affected and infected members, and in that case we pray for them on the phone and trust the Lord who started this work to finish it. (Apostle Ngobese)
\end{abstract}

Jentile (2020), Onumah and Nicolaides (2021) elaborated on the African worldview of spirituality which emphasized worshipping God together where there is no difference between believers and non-believers in advancing human rights, ubuntu and caring for each other. Idowu (2020) referred to Exodus chapters 7-12 to explain pandemics such as the plagues faced by Pharaoh for not releasing Israelites from Egypt and the sense of belonging together demonstrated by the church of Alice in Eastern Cape province.

"We are not allowed as per the Alert Level 3 regulations which ended yesterday (28 February 2021) to visit those who are affected and infected. We call them using Whatsapp calls and cell phones. We often visit old members of our congregations who are prevented by regulations to attend church services even those younger than 50 years are permitted. In such visits, we observe social and physical distancing. I did not experience any death in my church. I was infected when I attended funerals of my family members and family of school children which I teach, as both the pastor and a school principal." The finding by Jaja, Anyanwu and Jaja (2020) which linked churches in the Free State province of South Africa with the large scale infections by coronavirus and deaths which are now over 50000 by April 2020 are not a big factor in the Far North of KZN where the study was conducted.

Pastor Kubheka further stated her own suffering as a survivor of COVID 19.

It started as flue or a cough. My colleagues at school, asked me to stay at home. I did not feel any taste of food, everything I ate became tasteless and became powerless. My husband took me to the local doctor who conducted COVID 19 tests. During the next day, my results were back from the laboratory and I tested positive. My husband also tested positive, but he did not show most of the symptoms as I did. I had a challenge of breathing (isifuba kwakungathi siyabhoboka, ngezwa ngigodola), I was also feeling cold. When I was admitted, the Department of Health instructed my immediate family members to test for COVID 19 as well. All my children tested negative, and it was only me and my husband who were positive. I was not provided any treatment whilst I was in the hospital, I therefore decided to go home where I steamed with gum tree, eucalyptus oil and drank garlic, ginger and traditional herbs such as umsuzwane and umhlonyane. I was never given any treatment 
whilst in the hospital, but all of the above mentioned traditional herbs and the traditional healing processes brought me back to life. (Pastor Kubheka)

Hashmi et al (2020) came to a similar conclusion in a study conducted in Mount Lebanon regarding the use of sacred soil and water to treat coronavirus symptoms.

When churches reopened in June 2020, few churches managed to reopen because the regulation stipulated that they were supposed to decontaminate church buildings and always display a certificate which is evidence that the church building has been decontaminated. The churches were also expected to keep attendance registers, screen for temperature and sanitise those who enter church buildings whenever they congregate. Apostle Ngobese summarised the extent to which they comply with all of the above mentioned regulations.

We follow all the regulations stipulated by COGTA. We ensure that all believers fill their details in the attendance register, those who are showing COVID 19 symptoms are encouraged to stay at home until they test negative again. Ushers who received training from the District Department of Health are responsible for ensuring that believers enter their details in the attendance register, sanitise and undergo screening for temperature. (Apostle Ngobese)

Compliance with government lockdown regulations was a strong finding in South Africa which contradicted findings by Jaja, Anyanwu and Jaja (2020) who found the spread of coronavirus in the Free State Province of South Africa to be associated with pastors who disobeyed the regulations and asked their members to continue to congregate illegally. Wildman et al (2020) found many examples in South Korea, West Indies and USA of pastors who defied the lockdown regulations and continued to encourage their members to congregate as if there was no pandemic affecting the world at large.

Bishop Shangase explained more about his role as a member of the District Command Council

I teach believers and in particular pastors about COVID 19. I oversee the compliance of COVID 19 protocols by local churches and religious organisations as a convenor of the Jozini Local Municipality's Command Council. I was infected by COVID 19 at the beginning of the second wave. I was hospitalised for 2 weeks because I was showing symptoms of coughing, loosing appetite, power, had breathing problems, often vomited. I was tested and found to be COVID 19 positive and provided with oxygen to aid my breathing. After I regained my strength, I managed to start eating again. The symptoms take a long time to disappear, I still feel drowsy." Bishop Shangase also narrated power relations associated with the hospital treatment. He stated that "Hospitals treat well known people better than those who are not known. Initially I was not attended to, I waited for an ambulance for more than 2 hours. No one cared whether I ate or had any water to drink. I asked for blankets, but I was not provided anything, up until one nurse identified me as a pastor and a member of the Jozini Command Council, my treatment by hospital staff started to change for the better. I was then provided with blankets and placed on oxygen support up until I was discharged after two weeks in hospital. Bishop Zikhali indicated that "they assist people with first aid and refer them to local clinics (Bishop Shangase)

All the pastors were affected as they saw their believers and their family members dying in numbers. Apostle Ngobese narrated the following regarding the extent to which churches suffered as a result of COVID 19.

At my church, no one died, but people who used to sell goods during the pass over and other church ceremonies suffered a loss of income. As churches we are dealing with believers who are hungry as a result of the lockdown. We 
were traumatized as the COVID 19 is a new experience for us, church members are traumatized because they are not visited by pastors and fellow believers. Most female believers are affected by gender based violence. I was called in a family of believers where a young man poked his sister and mother with a knife, he was subsequently arrested and he is still in prison. Another problem is that as pastors we financially support poor members of our congregations as the bible states. We survive because there are few believers who are still paying their titles as stipulated in Malachi chapter 3 verses10-12. (Apostle Ngobese)

The World Health Organisation's (2020) guidelines prepared for religious leaders put more emphasis on the role of the church in dealing with gender based violence. The South African Government, especially President Ramaphosa mentioned gender-based violence which escalated more during the lockdown as one of the challenges the country need to address. The WHO (2020) recommendations for religious and faith based leaders also put more emphasis on promoting resilience, human rights based service delivery which is to a large extent promoted by various Bible verses.

\begin{abstract}
Bring the full amount of your tithes to the Temple, so that there will be plenty of food there. Put me to the test and you will see that I will open the windows of heaven and pour out on you in abundance all kinds of good things. I will not let insects destroy your crops, and your grapevines will be loaded with grapes. Then the people of all nations will call you happy, because your land will be a good place to live in. (Malachi 3:10-12)
\end{abstract}

In the Book of Deuteronomy chapter 14 verses $22-23$ and 27-29 the Law of the Tithe as well as the purpose is stipulated:

\begin{abstract}
Set aside a tithe- a tenth of all that your fields produce each year. Then go to the one place where the Lord your God has chosen to be worshipped; and there in his presence eat the tithes of your corn, wine, and olive-oil, and the first-born of your cattle and sheep. Do this so that you may learn to honour the Lord your God always. Do not neglect the Levites who live in your towns; they have no property of their own. At the end of every third year bring the tithe of all your crops and store it in your towns. This food is for the Levites, since they own no property, and for the foreigners, orphans, and widows who live in your towns. They are to come and get all they need. Do this, and the Lord your God will bless you in everything you do. (Deuteronomy 14:22-23, 27-29)
\end{abstract}

The participants reflected on their personal understanding of COVID 19. They shared their personal interpretation of events, experiences and perspective regarding what is happening in their respective churches in relation to the COVID 19 pandemic. The names given to COVID 19 by members of the community such as "Imikhovu ewu 19, ukhuvethe" and others seem to be different when it comes to church leaders who are unanimous that COVID 19 is a "curse which is caused by people who are disobedient to God" and therefore "it is the work of the Anti-Christ and they trace its origins to "hell" and in isiZulu two terms are used such as "esihogweni" and "emkhathini". Church leaders associate COVID 19 with the work of the devil, Anti- Christ and punishment from God for being disobedient. In a discussion most of the religious leaders had a deeper understanding of processes of managing COVID 19 such as isolation, testing, screening and quarantine.

There are personal reflections from Bishop Kubheka and Bishop Shangase who are church leaders who tested positive for COVID 19, were hospitalised, and quarantined for 14 days as part of their recuperation. In most of the churches which participated in the study, believers often undergo screening for temperature each time they congregate on Sundays. The church 
leaders experienced or witnessed the isolation of those who tested positive such as both bishop Shangase and Bishop Kubheka and it has become a practice in most religious institutions to screen members and visitors in temples as well as churches. Most of the religious leaders were informed by the media whilst others are part of structures such as command councils and received training regarding the management of COVID 19 offered by the Department of Health. Depending on the proximity to training facilities as well as structures responsible for managing COVID 19, some of the religious leaders possess basic knowledge whilst others got advanced knowledge regarding the management and prevention of COVID 19. Advanced indigenous knowledge of managing COVID 19 entails wearing a mask in public places, always washing hands using soap or a sanitiser regularly, ensuring that you bath when you arrive at home in the evening, leave your shoes outside the door, wash your clothes immediately especially after attending a funeral or a gathering attended by many people. It also entails steaming for 7 days a week, using gum tree and eucalyptus oil. Other approaches include drinking garlic, ginger and traditional herbs such as umsuzwane and umhlonyane.

These churches to a large extent comply with the regulations stipulated by the government and derived from the WHO guidelines. (WHO, 2020)

\section{Social distancing as one of government regulations introduced to reduce the spread of the pandemic}

The experience of pastors who participated in this study is that most funerals are characterised by large crowds, the limit to 50 mourners stipulated in Alert Level 3 regulations and 100 mourners stipulated during Alert Level 1 regulations is often not adhered to. At funerals, family members and neighbours are often not wearing any masks and do not maintain any physical and social distancing as required by law and common sense. Apostle Ngobese recalls the following:

"Bereaving families often do not adhere to the stipulated number of people allowed to attend a funeral. Over 200 people showed up in one funeral I presided over. In most places there is no ventilation provided for. There is at least one funeral service I attended where all the COVID 19 regulations were adhered to" Bishop Kubheka also recalled that ".... in two funerals where she buried church members, no COVID 19 regulations were adhered to". The reason for not adhering to the regulations, is the stigma associated with COVID related deaths, which similar to HIV related deaths, which make very few people to come forward if they suffer from coronavirus related ailments. Both Bishop Kubheka and Apostle Ngobese agree that "young believers are agents of change in their assemblies, and it is them who associate the coronavirus vaccine and the $5 \mathrm{G}$ related genetic engineering".

In the midst of all this confusion" pastors often provide COVID 19 messages when they preach. Some of the church buildings are too small to even cater for 50 people, therefore they remained closed even during Coronavirus Alert Level 1. Pastor Mathenjwa explained this better: "Churches are expected to allow 50 members to attend per session, our building which is just smaller than a classroom cater for only 10-15 members, and we were unfortunately expected to remain closed, and rely on social media to continue to worship".

Failure to adhere to physical and social distancing protocols are found in The Netherlands, Canada, South Korea, USA, Trinidad, and South Africa according to various studies including Vermeer and Kregting (2020), Parish (2020), Cherblanc et al (2021), Wildman et al (2020), Jaja, Anyanwu and Jaja (2020). This failure to adhere is thus a global practice which is not limited to the Far North of KwaZulu Natal alone. 
Bishop Zikhali had this to say about social distancing:

\begin{abstract}
We apply social distancing if possible, but we are unable to control people who consume liquor who often share a bottle of beer. As churches we adhere to social distancing regulations, we check temperature time and again. There was a member who came back from a family funeral in Zululand District and her temperature was very high. The explanation we received is that she washed a body of the deceased who was diagnosed with COVID 19. She was admitted at Mseleni Hospital for 3 weeks before she died. The husband who also tested positive survived by escaping from the hospital. The late wife was a teacher and a sole breadwinner and her husband is unemployed. As a church we took over to support the husband and his children.
\end{abstract}

Social intimacy is often affected by coronavirus. Apostle Ngobese indicated that coronavirus did not change issues of social intimacy in his home. "There is no social distancing when I reach home, no one wears a mask when we are at home, I still share a bed with my wife". Bishop Kubheka support the view that "coronavirus is demonic as it attempts to cause splits in the families". In the Book of Genesis chapter 2 verse $18 \mathrm{God}$ is cited verbatim by Moses where He emphasised intimacy: "It is not good for a man to live alone. I will make a suitable companion to help him". Pastor Mkhaliphi indicated that the messages from government are often misleading, "for instance, the message on billboards is that crowds are super-spreaders of the virus, in my bedroom, it is only the two of us, but we are told that because both me and my husband contracted a virus, we were supposed to live in isolation from each other. This is un-biblical and against God's will". In most churches "if you are affected by COVID 19, people think that you are not a true believer, and it is worse if you are a pastor, how can a pastor suffer from "isifo saseMkhathini?" Bishop Zikhali indicated that as much as he supports social intimacy, he cautioned against failure to comply with the rules to maintain physical distancing, even if people are married.

The findings above confirm the writings and findings by Koening (2020) and Hashmi et al (2020) regarding faith in God and illnesses such as coronavirus that are associated with sinners and God's intervention to heal those who have faith in Him. "As much as the Bible promotes intimacy, we still need to comply with the regulations. We still have each other spiritually and adhere to the Word without any physical intimacy".

In a local Nazareth Baptist Church, under the Prophet Unyazi LweZulu, more than 100 people come together during a Sabbath, because it is an outdoor event. The local prophet visits all temples in the district to monitor compliance with regulations. The local prophet explains the new temple protocols brought about by COVID 19.

\begin{abstract}
We no longer lay hands on people, but use a cloth to pray for people and Unyazi LweZulu will touch them without us laying hands on them. We bless the water they will drink. We provide people with masks as they enter the temple, unfortunately we are unable to screen and test for temperature, we hope that Unyazi LweZulu takes over.
\end{abstract}

There is also a view from the church that God is the only one with the powers to protect believers from COVID 19.

Bible verses were cited to confirm God's powers to heal people from coronavirus. In the Gospel according to Matthew chapter 8 verses 1-4, 5-13, 14, 30-34, Jesus healed a man who suffered from "a dreaded skin disease", at Capernaum, He healed a Roman officer's servant. In Peter's house, Jesus healed his mother in law who was suffering from fever. The Gospel according to Matthew, chapter 8 verses $14-15$ states this clearly. Similar miracles are also found in the Gospel according to Mark Chapter 1 verses 1-40, Luke chapter 5 verses 12-16, 
and Luke 7 verses 1-10: “Jesus went to Peter's home, and there he saw Peter's mother-inlaw sick in bed with a fever. He touched her hand; the fever left her, and she got up and began to wait on him".

The healing of Peter's mother-in-law is confirmed in the Gospel according to Mark chapter 1 verses 29-34 as well as the Gospel according to Luke chapter 4 verses 38-41. In the Gospel according to Matthew chapter 8 verse 16, Jesus healed the crowds who were demon possessed and in verses 28 Jesus healed two men who were demon possessed and the demons moved from people to pigs (Matthew, 8 verse 31 ). This miracle is also confirmed in the Gospel according Mark chapter 5 verse 1-20 as well as Luke chapter 8 verses 26-39. Jesus also healed a paralysed man. This is stated in the Gospels according to Matthew, Chapter 9 verses 1-7, Mark chapter 2 verses 1-12 and Luke chapter 5 verses 17-26. The Gospel according to Luke chapter 5 verses 18-26 explain this miracle better:

\begin{abstract}
Some men came carrying a paralysed man on a bed, and they tried to take him into the house and put him in front of Jesus. Because of the crowd, however, they could find no way to take him in. So they carried him up on the roof, made an opening in the tiles, and let him down on his bed into the middle of the group in front of Jesus. When Jesus saw how much faith they had, he said to the man "Your sins are forgiven, my friend". "I tell you, get up, pick up your bed and go home. At once the man got up in front of them all, took the bed he had been lying on, and went home, praising God. They were all completely amazed! Full of fear, they praised God saying, "What marvellous things we have seen today.
\end{abstract}

The Bible confirmed the view and the belief of various pastors who are hoping for God's intervention to heal the victims of the coronavirus as he did in front of the masses in Biblical times.

\title{
How hygiene and sanitation regulations were carried out during lockdown.
}

The WHO (2020) guidelines for religious leaders place emphasis on their role to promote hygiene and sanitation. In order to curb the spread of the coronavirus, religious institutions are expected to decontaminate the buildings in which they worship, and provide water and soap for worshippers to wash their hands regularly. They are also expected to screen those who come for religious purposes and take down their details, as well as provide sanitisers in each and every twenty minutes of sermons. Bishop Shangase indicated that there is a lack of water in most parts of Jozini especially at Sibongile where she often conducts sermons. Her attempts to engage ward councillors did not yield any results. Pastor Mantengu also emphasised that:

\begin{abstract}
Water is a problem in most parts of Jozini, even money to purchase sanitisers is not available and the health and hygiene protocols are not affordable in most churches. The government is far away from the churches, we are expected to decontaminate church buildings before we worship, but no assistance was provided in the same manner as the schools and the businesses who were provided with money from the relief fund to rebuild their businesses.
\end{abstract}

The churches also complain about a lack of support in poverty alleviation from government agencies. Pastor Mkhaliphi stated that: "Churches closed down at the end of March 2020, but when they were expected to reopen, thermometers, marks, gloves and other protective equipment were not provided. We were expected to purchase PPEs, sanitisers and even decontaminate our church buildings without any assistance from the government". The local prophet of the Nazareth Baptist Church, outlined the following protocols conducted during funerals: 
We revised our protocols due to COVID 19 outbreak. We receive the body from the mortuary in the morning and no longer in the evening. We no longer open a coffin and place a body in a blanket. Unyazi LweZulu instructed us to no longer remove a body from a coffin as we used to do. These funerals are no longer dignified as in most instances we buried wrong bodies. We now use a leaf called Umlahlankosi to communicate to the dead as we rebury them using the original protocols of the Nazareth Baptist Church. In my family, I buried my wife and a son who arrived on a plastic bag, we did not open their bodies as instructed by Unyazi LweZulu. After the funeral I took the Umlahlankosi leaf and collected their spirits from Richards Bay where they died. They both came from the mortuary and the bodies were buried without being taken home for our usual rituals. We slaughtered goats to appease the spirits of the deceased and ancestors. For members of the church, I do not prescribe the protocols, I support whatever approach they adopt given the circumstances.

The costs of conducting funerals in traditional communities increased due to the coronavirus protocols which imply that a funeral is conducted twice.

\section{Membership of the Command Council, the role of churches and consultations by government}

Jozini is the only local area where pastors serve in a Command Council chaired by the Mayor of Jozini Local Municipality. Mtubatuba, Hlabisa Big Five and uMhlabuyalingana local councils did not invite local pastors and religious leaders to join structures established to manage the spread of coronavirus. Religious leaders were consulted by the Department of Health and sometimes by virtue of their membership of the local Command Councils, they often obtained training and information related to COVID 19. The role of the churches was not well explained. Pastor Mkhaliphi indicated that "our role was not explained to us, not all pastors were trained as agents of social change, the focus was how to observe the protocols when churches reopen after the lockdown".

The message conveyed was that churches who were failing to meet the requirements such as decontaminating church buildings, providing sanitisers, screening and others, were advised not to reopen such churches. The church buildings as well as places of worship are not the same as in some churches where people "worship in garages and people come to churches so that pastors lay hands on them, and only to find that pastors are no longer allowed to lay hands on people, some members are not on whats app, they are only accessed through the phone, out of 50 members only 15 constantly have data they could use to access online sermons or participate live every Sunday. (Apostle Ngobese)

For churches to comply with the COVID 19 regulations, Pastor Mbatha asserted that they need "financial and logistical support from the government, be trusted to assist in distributing food parcels instead of politicians who use this as part of political patronage, government to include pastors in planning, government need to partner with churches in the fight against crime, gender based violence". Churches are more than ever before expected to fight crime, unemployment and COVID 19, and therefore collaboration with state institutions is essential.

Bishop Zikhali outlined the role of the church in dealing with COVID 19 as follows:

As much as we are expected to assist as a church, but we are affected as we witness the death of our members as a result of corona related illnesses. We find ourselves decontaminating houses of our members after the funeral of a member because government is not assisting. This is because in some 
households, none of the members are employed and thus have no income whatsoever. We assist with post-mortems because some funeral parlours do not conduct post-mortems and corona related deaths are treated as just natural causes. We found that neighbours attend funerals and thus limit prospects of social distancing. In funerals, we often provide masks because none of the government agencies are willing to assist with any PPEs. PPEs are often not sold locally and we travel to Empangeni to purchase masks, sanitisers and other PPEs. (Bishop Zikhali)

Bishop Zikhali further elaborated that "In our church we assisted a family to isolate after they contracted a virus by providing them with an alternative building, after 10 days of isolation, all members tested negative. A church member lost a child and we supported them financially. We use our church funds to support needy families. Our members continue to use EFT to pay their tithes regularly in order to support widows and other vulnerable members of our church."

\section{Conclusion}

The experiences of the religious leaders in the Far North of KZN are similar to those across the globe including some African countries such as Uganda. There is no doubt that coronavirus pandemic led to many churches being forced to close down, whilst those in various parts of uMkhanyakude cooperated with the state and adhered to COVID 19 protocols such as social distancing. Churches introduced new means of praying and supporting their members remotely, whilst continuing with most of the ceremonies using online platforms, including for an example online church services conducted on Sundays as well as the 2020 Passover ceremonies which were conducted using online platforms due to the fact that most of the countries were undergoing lockdown. As much as the role of the church is still not explained in greater detail in various government regulations as indicated in WHO guidelines, religious leaders availed themselves to support the state in its endeavours to protect lives and prevent the spread of the coronavirus.

The religious leaders appeared to be champions of driving innovations in the manner in which they handled funerals, adhered to COVID 19 regulations by limiting the number of people who attended funerals, promoted the culture of wearing masks and by maintaining health and hygiene practices. The need for the government to partner with religious leaders and religious institutions is clearly supported and encouraged by the church. The experiences are rich and diverse regardless of the Pentecostal, Protestant and African Indigenous nature of the church formation. The experiences as ascertained in this study need to be taken into cognizance when formulating policies and regulations. The membership of various local command councils assisted many religious leaders to be more informed on the nature and strategies to manage coronavirus and such initiatives are important and useful.

\section{References}

Baker, J.O., Marti, G., Braunstein, R., Whitehead A.L. \& Yukich, G. (2020). Religion in the Age of Social Distancing: How COVID-19 Presents New Directions for Research. Sociology of Religion: A Quarterly Review, 81(4), 357-370.

Cherblanc, J., Bergeron-Leclerc, C., Maltais, D., Cadell, S., Gauthier, G., Labra, O. \& OuelletPlamondon, C. (2021). Predictive Factors of Spiritual Quality of Life during the COVID-19 Pandemic: A Multivariate Analysis. Journal of Religion and Health, 1-19

Clark, M.S. (2005). Two Contrasting Models of Missions in South Africa: The Apostolic Faith Mission and the Assemblies of God. Asian Journal of Pentecostal Studies, 8(1), 143-161. 
Frei-Landau, R. (2020). "When the Going Gets Tough, the Tough Get-Creative": Israeli Jewish Leaders Find Religiously Innovative Ways to Preserve Community Members' Sense of Belonging and Resilience During the COVID-19 Pandemic. Psychological Trauma: Theory, Research, Practice and policy, 12(51), S258-S260.

Fardin, M.A. (2020). COVID-19 Epidemic and Spirituality: A Review of the Benefits of Religion in Times of Crisis Journal of Religion and Health, 59:2697-2700

Hashmi, F.K., Iqbal, Q., Haque, N. \& Saleem, F. (2020). Religious Cliché and Stigma: A Brief Response to Overlook Barriers in Covid-19 Management. Journal of Religion and Health, 59,2697-2700.

Henderson, E.S. (2021). A Global Perspective on the COVID 19 Crisis and an Ontological Perspective. Pharos Journal of Theology, 102,1-19.

Idowu, E.A. (2020). Covid-19 in Alice: Synthesizing Church growth with pandemic movement using the approach of Exodus 7-12. Pharos Journal of Theology, 101,1-15.

Isiko, A.P. (2020). Religious construction of disease: An exploratory appraisal of religious responses to the COVID-19 pandemic in Uganda. Journal of African Studies and Development, 12(3), 77-96.

Jaja, I.F., Anyanwu, M.U. \& Jaja, C.I. (2020). Social distancing: how religion, culture and burial ceremony undermine the effort to curb COVID-19 in South Africa. Emerging Microbes and Infections, 9,1077-1079

Jentile, T. (2020). 'ICawa ivaliwe': The Church During the Pandemic, Pharos Journal of Theology, 101, 1-15.

Koening, H.G. (2020). Maintaining Health and Well-Being by Putting Faith into Action During the COVID-19 Pandemic, Journal of Religion and Health, 59, 2205-2214

Kowalczyk., O., Roszkowski, K., Montane, X., Pawliszak, W., Tylkowski, B \& Bajek, A. (2020). Religion and Faith Perception in a Pandemic of COVID-19. Journal of Religion and Health, $59,2671-2677$

Masoga, M.A. (2020a). The Crumbling Empire? Liberation Theological Investigation into the Impact of COVID-19 on South African Communities. Pharos Journal of Theology, 101,1-17.

Masoga, M.A. (2020b). Effectiveness of WhatsApp homiletics in the era of COVID-19 in South Africa. Pharos Journal of Theology,101:1-16.

Ngozwana, N. (2018). Ethical Dilemmas in Qualitative Research Methodology: Researcher's Reflections. International Journal of Educational Methodology, 4(1), 19-28.

Nicolaides, A. (2021a). Investigating the Holy Eucharist and the term 'people of God' according to the Eastern Orthodox Church. Pharos Journal of Theology, 102,1-9.

Nicolaides, A. (2021b). Theological Eastern Orthodox teachings and Ethical Business Practice for the $21^{\text {st }}$ Century. Pharos Journal of Theology, 102,1-14.

Onumah, J.M. \& Nicolaides, A. (2021). Human Rights and Eastern Orthodox Understanding and Teachings doer a Troubled World. Pharos Journal of Theology, 102,1-14.

Parish, H. (2020). The Absence of Presence and the Presence of Absence: Social Distancing, Sacraments, and the Virtual Religious Community during the COVID-19 Pandemic. Religions, 11(276), 1-13. 
Pityana, B. (2020). More eyes on COVID-19: Perspectives from Religion Studies: How Christian theology helps us make sense of the pandemic. South African Journal of Science, 116(2/8).

Shokane, A.L. \& Masoga, M.A. (2020). An Afro-sensed perspective on decolonising research methodologies Chapter 2 in de Vos, A.S., Strydom, H., Fouche, C.B., and Delport, C.S.L (editors) (2020) Research at Grass Roots- For the Social and Human Science Professions $\left(5^{\text {th }}\right.$ edition) Pretoria: Van Schaik Publishers.

Vermeer, P. \& Kregting, J. (2020). Religion and the Transmission of COVID-19 in The Netherlands. Religions, 11(393),1-12.

Wildman, W.J., Bulbulia, J., Sosis, R. \& Schjoedt, U. (2020). Religion and the Covid-19 pandemic. Religion, Brain and Behaviour, 10(2), 115-117.

World Health Organization (2020). Practical considerations and recommendations for religious leaders and faith-based communities in the context of COVID 19. New York: World Health Organization 